\title{
The Influence of Electronic Word of Mouth, Value Co-Creation and Brand Image on Trust
}

\author{
Abror Abror ${ }^{*}$, Silvi Ayuni ${ }^{2}$, Yunita Engriani ${ }^{3}$ \\ 1 Universitas Negeri Padang, Padang, Indonesia, $\triangle$ abror094@gmail.com; abror094@fe.unp.ac.id; \\ 2 Universitas Negeri Padang, Padang, Indonesia, $₫$ silviayuni96@gmail.com; \\ ${ }^{3}$ Universitas Negeri Padang, Padang, Indonesia, $\bowtie$ yunitaengriani@gmail.com; \\ *Corresponding author
}

\begin{abstract}
This research aims to analyze: (1) the influence of brand image on E-Word of Mouth of Wardah in Padang city (2) the impact of brand image on customer trust (3) the influence of value co-creation on E-Word of Mouth (4) the influence of value co-creation on brand image (5) The influence of value co-creation on trust, and (6) the influence of trust on E-Word of Mouth. This research is a causative research. The population on this research is all students who use Wardah cosmetics in Padang. The total number of samples in this study are 80 students who have been selected by using purposive sampling due to unknown the number of populations. This study found that (1) brand image has no significant direct effect on EWord of Mouth (2) brand image has a significant effect on trust (3) value co-creation has a significant effect on E-Word of Mouth (4) value co-creation has a significant effect on brand image (5) value co-creation has a significant effect on trust (6) trust has a significant effect on E-Word of Mouth. Some limitations and further studies are discussed.
\end{abstract}

Keywords: electronic word of mouth, value co-creation, brand image, trust

\section{Introduction}

Nowdays, cosmetics and skincare have got more attentions of the customers. Hence, it might have an impact on the economic growth. According to The Ministry of Industry of the Republic of Indonesia (2017), the national cosmetics industry recorded a growth of $20 \%$ or four times from the national economic growth and the domestic cosmetic industry increased around 153 companies, thus the amount more than 760 companies. According to previous research stated that, a number of cosmetic companies around the world are competing with each other to get a billion dollar cosmetics market share (Rastogi S.C, 2003). Most cosmetic companies have offered varieties of product categories that are widely held with various brands local and international. In principle, the target customers of cosmetic companies are female consumers (Dumonceaux, et.al,. 2006).

In this globalization era, competition between companies is getting tighter. Thus each company will strive to maintain the trust of the company in order to survive. There are many ways that can be used by companies to produce the best results on their products in order to get a high level of trust on consumers. There are several factors in this study that discuss the influence of electronic word of mouth (EWOM), value co-creation and brand image toward trust.

Wardah is one example of a company engaged in cosmetics and skincare that has gained attention and great demand by consumers. Various types of Wardah products on the market that have gained trust by consumers. Wardah is known as halal brand cosmetic and skincare that popular in Indonesia and overseas. According to Kumparan (2017), Top 10 of the most popular female cosmetic brand in Indonesia during 2016: Wardah (37,8\%), Pixy (10,1\%), Sariayu $(8,7 \%)$, Viva $(6,6 \%)$, Ponds $(6,6 \%)$, Latulip (3,9\%), Oriflame (3,6\%), Maybeline (3,3\%), Revlon (2,9\%) dan Mustika Ratu (1,9\%). According to CNN Indonesia (2018), Wardah is also a pioneer of halal cosmetic products that are in great demand by domestic and overseas. Wardah halal cosmetics The Republic of Indonesia is the third largest exporter in Malaysia.

One thing that will be observed in this study is how Wardah can increase its trust in consumers among students. Where Wardah is always active in giving talk shows and beauty classes that provide 
education so that student are more aware of healthy makeup by prioritizing ingredients from the cosmetics used. Cosmetics is one industry that is aware of electronic communication strategies of word of mouth, because online product reviews are one of the things that are often discussed by women today. Wardah as a large company certainly has many competitors and also has positive and negative reviews through online media.

Value co-creation is considered to be a solution to problems that exist in Wardah, because this method can establish relationships between consumers and producers, so that consumers can collaborate with Wardah through the suggestions and ideas given.Wardah will always make new products that are in line with the current trend and accept advice given by consumers directly or through social media.

Not only EWOM and the value co-creation that has become a consumer factor trust in Wardah products, but also the brand image that has existed for a long time in these products. Wardah is one of the mainstay products produced by PT Paragon Technology and Innovation (PTI) which has been established since 1985. Wardah products are made from safe and halal raw materials. Nowadays, Wardah is quite active in promoting their products through the internet, such as Instagram (Wardahbeauty), Website (www.wardahbeauty.com), YouTube (Wardahbeauty), and Facebook (Wardahcosmetics). So it is no wonder why Wardah brand image has been very attached among cosmetics and skincare products, although there are many choices of local and international brands that are circulating in the market.

This research will gives two contributions. First, theoretical to provide an overview of the theoretical framework, and provide a contribution to further research in the field of marketing and also provide additional literature in the study of marketing strategies. Second, practical to help marketing managers in policy making decision.

Hart and Saunders (1997) and Lien et al. (2015), claiming that trust is something that represents the level of trust from other parties which will involve what is expected. Whereas according to Rousseau et al. (1998) Trust has been defined as psychological consisting of intention to accept based on positive expectations of the intentions or protection of others. Therefore, trust will not be needed, if done with complete and riskless certainty. According to other authors, Rempel et al. (1985), trust is trusting others and considers intrinsic motivation in a partnership. Furthermore, Mayer et al. (1995). The relationship of trust is one party that is vulnerable to the actions of other parties, based on the expectations of other parties who will take important actions for the assignor, regardless of their ability to facilitate or control.

The concept taken for trust in this study is one that Karlsen et al. (2008) and (Rose \& Schlichter, 2013), who criticized the statement of Rousseau et al. (1998), because for them it is not a moral imperative or an individual's psychological condition, but an ordinary component in the organization and the consequences of interaction between two parties, with a direct relationship with the reaction in response to an action. From the opinion of some experts, it can be concluded that trust is the interaction between several parties that represent the level of trust of other parties who will act as expected.

Brand image is a gateway for customers to recognize a product, evaluate quality, understand and reconcile purchasing risk, and gain certain experience and satisfaction (Nagar, 2015). Brand image is the case with the mind and even though there are certain brands, so that the brand image has more to do with psychological factors than the physical factors of a particular brand. Furthermore, according to Xian and Gou Lie (2011: 2), there are some components that are brand images, namely Citrones Perusus, the Citizen Consumer, and many products. From the expert's opinion above, it can be concluded that the brand image is important, which needs to be taken care of by the company. Consumers tend to make a brand image as a matter of judgment or before buying a brand on a product or so. However, the company can create a brand image that goes down and causes a product that is just like it wants and needs consumers so that consumers have a positive image of that brand.

Co-creation is defined and conceptualized as active participation, interaction, dialogue and collaboration between buyers and sellers and other parties in marketing exchanges to develop a 
deeper understanding of the context of solving customer problems. Social-emotional activity or building relationships that encourage trust through influence when parties are involved in knowledge exchange and exchange of ideas (Swift \& Hwang, 2013). According to Merz, He, and Vargo (2009) define co-creation value as a dynamic engagement and interaction between customers and suppliers. According to logic, dominant through customer service can actively interact with organizations in the process of designing, making, and distributing products or services.

Furthermore, according to Seraj (2012), co-creation value can be divided into two types: customer co-creation value and firm-sponsored cocreation value. Although it is difficult to separate these types, it is usually because co-creation values are built on factors such as interaction, self-service, and involvement, all of which require customers and companies. Therefore, this study focuses on customer co-creation values initiated by certain psychological conditions, namely the conditions of persistent positive affective-motivational fulfillment (Hsieh \& Chang, 2016). From the opinion of the experts above it can be concluded that value co-creation is the value of involvement between consumers and companies, where consumers and companies can work together to create a product. Customers actively interact with the company in providing information and ideas to create new products that are popular with the market. So that it has a positive impact on the company in distributing goods to the market in order to be well received.

Electronic word-of-mouth (EWOM) is defined as statements, positive or negative, made by potential, actual or former products or services, which are made available to other via the internet (Hennig-Thurau, Gwinner, Walsh, \& Gremler, 2004; Cheung, Lee, \& Rabjohn, 2008; Cheung, Lee, \& Thadani, 2009; Chu \& Choi, 2011; Jalilvand, Esfahani, \& Samiei, 2011; O'Reilly \& Marx, 2011; Pan \& Chiou, 2011; Jalilvand \& Samiei, 2012; Jalilvand, Samiei, Dini, \& Manzari, 2012; Lim, Chung, \& Pedersen, 2012; Lin, Lu, \& Wu, 2012). Furthermore, EWOM Information also helps consumers shape the expectations of a brand before buying because EWOM information reduces uncertainty in the decision-making process for consumers (Krishnamurthy and Kumar, 2015).

Kotler and Keller (2016: 645) state that social media is one example of EWOM. Social media is a means for consumers to share information in the form of reviews, images, audio, and videos with each other and with companies and vice versa. Social media allows marketers to build public voices through online presence. They can cost effectively strengthen other communication activities. Because of their daily activities, they can also encourage companies to remain innovative and relevant. From the above definition it can be concluded that the major impact of EWOM can be seen directly from social media or online reviews. Where these reviews can be seen by consumers through a variety of online information media, as well as a major impact on market conditions that will influence purchasing decisions for consumers.

Brand image is an antecedent of word of mouth (Wang, Wang, Xue, Wang, \& Li, 2018; Anggraeni \& Rachmanita, 2015). Klein, Falk, Esch, and Gloukhovtsev (2016) have asserted that brand experience which is related to brand image will lead to word of mouth. When a customer has got an excellent experience, it means that he/she will have a good image with the product or services, thus he/she will try to recommend that product to others. Moreover, Filieri, Alguezaui, and McLeay (2015) argue that experience of the customer in consuming a product will have an impact on his/her willingness to recommend that product to other. Whilst, the customer experience is the source of the brand or product image. Accordingly, we argue that the brand image will lead to the customer's willingness to recommend that product.

In terms of market competition, Severi and Ling (2013) emphasized that a strong brand image can strengthen brand competitiveness. Brand image, as a factor for decision making, tends to be shaped by consumer impressions and experiences, representing their overall knowledge of a particular brand, according to Budiman (2015). Based on previous research, this study views brand image as an important factor that influences the level of satisfaction and customer trust levels.

Customer value co-creation may have an impact on the customer willingness to promote the product (Cossío-Silva, Revilla-Camacho, Vega-Vázquez, \& Palacios-Florencio, 2016; Banyte \& Dovaliene, 2014). Xie, Tsai, $\mathrm{Xu}$, and Zhang (2018) have highlighted that customer value co-creation is 
a positive antecedent of word of mouth. Customers with high value co-creation mean that they will have better involvement with the product or company. Hence, the customers will have a bigger chance to participate in promoting the product to other people. Accordingly, we argue that customer value co-creation will have a significant impact on E-WOM.

According to (Hatch and Schultz, 2010; Ind and Coates, 2013; Payne et al., 2009; Thatcher et al., 2016), Value Co-Creation is a distinctive joint innovation through value and experience in customer participation and other stakeholders. So according to Lebeau and Bennion (2014), Co-Creation value requires continuous interaction between companies and consumers, where both parties combine and integrate resources (to some extent) to help advance the business and build their reputation in the market. Even consumer participation in value creation can also influence other stakeholders' perceptions of the company, according to expert Ind and Coates (2013). Thus value co-creation has a relationship with the brand image because it can build a company's reputation and have a positive impact on a company.

According to previous research (Leadbeater, 2006; Lundkvist \& Yakhlef, 2004), that a higher level of customer co-creation will also result in a higher level of trust among buyers and suppliers. Risk, and risk reduction, also play a role here. Where the collaborative approach to solving problems involves deliberate exposure and sharing of information and resources of both parties. Therefore, several levels of trust are needed to fight intentional vulnerability to exploitation that has been opened by partners. It can be concluded that one of the reasons for co-creation value leads to trust is because the act of co-creation requires several levels of trust to offset the risks generated by open information exchanges between partners.

According to Casalo et al. (2011), the trust given by members of the online travel community has a significant importance to attitudes through advice. Their findings indicate that increasing consumer confidence in eWOM will ultimately lead them to support a good attitude towards it. They explain more about this, perhaps the reason consumers choose more than informal and personal communication sources from formal and organizational sources in making their purchasing decisions. Ayeh et al. (2013) that supports consumers' intention to use E-WOM for trip planning. The results of the study indicate that the existence of their trust will have an impact on E-WOM because it has a positive influence on attitudes towards the use of advice for trip planning. Therefore, in this study, the following hypothesis is proposed

\section{Methods}

The type of research that will be conducted is causative research. Thus, research explains and illustrates the relationship between the independent variables of E-Word of Mouth, Value CoCreation and Brand Image, the dependent variable is Trust. The population in this study are all Student users of Wardah products in Padang City whose numbers are unknown. The sample that will be used in this study considered are customers who ever owned and or intend to own Wardah products by taking sample of 80 respondents. The research instrument used was the questionnaire given to the respondents. The measurement used to measure the respondent's response is to use a Likert scale with a scale range of 5 = "Strongly Agree (SS)" to 1 = "Strongly Disagree (STS)".

This research evaluates the outer model and evaluate the inner model before testing the hypothesis. Evaluation of the outer model is done by using validity and reliability tests to obtain representative data which will be further analyzed. In testing the validity uses convergent validity (convergent validity) and discriminant validity (discriminant validity), while reliability is tested by using statistical composite reliability. Evaluation of the inner model has been done by using predictive-relevance (Q Square). 
Table 1 Research Variables

\begin{tabular}{llll}
\hline \multicolumn{1}{c}{ Variable } & & \multicolumn{1}{c}{ Indicators } & \multicolumn{1}{c}{ Source of } \\
\hline Trust & 1. & Trust this brand & Zohaib et.al (2014) \\
& 2. & Rely on this brand & \\
3. & honest brand & \\
4. & Brand that meets expectations & \\
5. & Safe brand
\end{tabular}

Electronic Word of Mouth

1. Say positive things to others

Wardi et.al (2018)

2. Recommend to others

3. Supporting colleagues to do business online

Brand Image

1. Distinguishable

Kim et al. (2016)

2. Personality

3. Unique image

4. Intriguing

Value Co-Creation

1. Look for information about

Alves et al. (2016) services from companies, both online and offline

2. Provide information that is appropriate and necessary to ensure good service delivery

3. Provide service or make contact with the company requested

4. Provide service or make contact with the company, and have a pleasant attitude towards company staff members

5. Give opinions and ideas to the company about services, both online and offline

6. Give advice about services to other customers

7. Recommend company products to other consumers

8. Have a certain tolerance for the possibility of failure of the company's product service

Testing the hypothesis in this study using Partial Least Square (PLS). Testing this hypothesis is done to see the relationship between variables. For more details, the variables in this study can be seen in Table 1.

\section{Results and Discussion}

Evaluation Outermodels madeto test the validity and reliability of data. Validity test consists of convergent validity and discriminant validity, while reliability is tested using statistical composite reliability. 
Convergent Validity There is an indicator that meet the convergent validity if it has a valuea factor loading above of 0.5 . The following is the result of convergent validity for variables employee attachments, job satisfaction and OCB. Results convergent validity can be seen in Table 2.

Table 2 Convergent Validity

\begin{tabular}{lccc}
\hline \multicolumn{1}{c}{ Variable } & Indicator & Factor Loading & Specification \\
\hline Trust & T1 & 0888 & Valid \\
& T2 & 0907 & Valid \\
& T3 & 0858 & Valid \\
T4 & 0867 & Valid \\
& T5 & 0848 & Valid \\
& & & \\
Electronic Word of & EWOM1 & 0854 & Valid \\
Mouth & EWOM2 & 0948 & Valid \\
& EWOM3 & 0919 & Valid \\
Brand Image & & & \\
& BI1 & 0786 & Valid \\
& BI2 & 0883 & Valid \\
BI3 & 0886 & Valid \\
Balue Co-Creation & BI & 0870 & Valid \\
& & & \\
& VCC1 & & Valid \\
& VCC2 & 0672 & Valid \\
VCC3 & 0800 & Valid \\
VCC4 & 0820 & Valid \\
& VCC5 & 0839 & Valid \\
VCC6 & 0860 & Valid \\
VCC7 & 0880 & Valid \\
VCC8 & 0823 & Valid \\
& & 0798 &
\end{tabular}

Source: Secondary Processing Data 2019

Based on results the output in Table 2 show that the factor loading for each construct the above required 0.5 to 0.6 . Based on the results of the analysis it is known that all items have a factor value loading greater than 0.5 so that all constructs of trust, electronic word of mouth, brand image and value co-creation have good validity.

Discriminant Validity Discriminant Validity can be seen from the Average Variance Extracted (AVE). Constructions with good validity require AVE values to be above 0.5. The results of discriminant validity can be seen in Table 3.

Table 3 Average Variance Extracted (AVE)

\begin{tabular}{lcc}
\hline \multicolumn{1}{c}{ Variable } & AVE & Information \\
\hline Trust & 764 & Valid \\
\hline Electronic Word of Mouth & 824 & Valid \\
\hline Brand Image & 734 & Valid \\
\hline Value Co-Creation & 662 & Valid \\
\hline
\end{tabular}

Source: Secondary Data Processing 2019 
Based on Table 3 above shows that thefactor value is loadingAverage Variance Extracted (AVE) each loading factor value construct variable is above 0.5 , so it can be concluded that all construct variables in this study are valid.Reliability Reliability test is done using statistical composite reliability, where the value of composite reliability above 0.7 is the expected value. The results of the reliability test are shown in Table 4.

Table 4 Value Composite Reliability

\begin{tabular}{lcc}
\hline Variable & Composite Reliability & Specification \\
\hline Trust & 0942 & Reliable \\
\hline Electronic Word of Mouth & 0934 & Reliable \\
\hline Brand Image & 0917 & Reliable \\
\hline Value Co-Creation & 0940 & Reliable \\
\hline
\end{tabular}

Source: Secondary Data Processing 2019

Based on Table 4 it can be seen that thevalue of composite reliability the third study variable values above 0.7, thus it can be concluded that trust, electronic word of mouth, brand image and value co-creation have been reliable, because they have fulfilled composite reliability the expected. Testing goodness of fit models structural in the inner model using model predictive-relevance (Qsquare). The value of $\mathrm{R}$ - square from each endogenous variable in this study can be seen in Table 5 .

Table 5 Value R-Square Endogenous

\begin{tabular}{lc}
\hline Endogenous Variable & Value R-square \\
\hline Electronic Word of Mouth & 0.594 \\
\hline Brand Image & 0.554 \\
\hline Trust & 0.579
\end{tabular}

Source: Secondary Data Processing 2019

The assessment of goodness of fit is known from the Q-square. The Q-square value has the same meaning as the coefficient of determination (R-square) in the regression analysis. The higher the Qsquare, the model can be said to be more fit with the data.

The results of calculating the Q-valuesquare are as follows:

Q-Square $=1-[(1-0.594) \times(1-0.554) \times(1-0.579)]$

$$
\begin{aligned}
& =1-[0.406 \times 0.446 \times 0,421] \\
& =1-0.076=0.923
\end{aligned}
$$

From the calculation results, the value Q-square has obtained greater than $0(0.923>0)$, so it can be interpreted that the model is good because it has a relevant predictive value of $92.3 \%$. That is, the magnitude of the diversity of research data that can be explained by the research model is $92.3 \%$, while the remaining $7.6 \%$ is explained by other factors outside the model. Based on these results, the research model has good goodness of fit. 


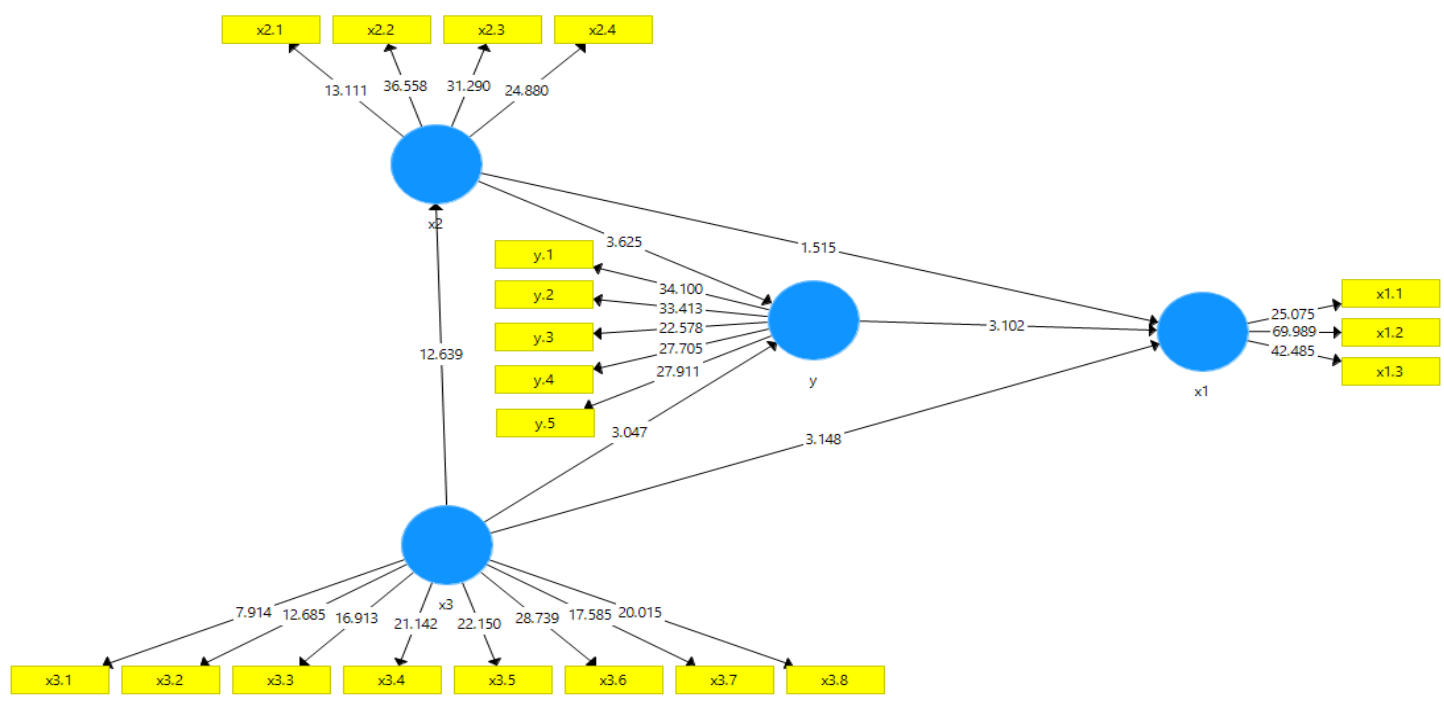

Figure 1 Output Analysis

Based on Table 6, we found that all hypotheses are supported, except hypothesis 1.

Table 6 Results of Standard Deviation (STDEV), T-statistics and P-values

\begin{tabular}{|c|c|c|c|c|c|}
\hline Hypotheses & Relationship Effect & $\begin{array}{l}\text { Standard } \\
\text { Deviation } \\
\text { (STDEV) }\end{array}$ & T-statistics & P-values & Description \\
\hline$\overline{\mathrm{H} 1}$ & $\begin{array}{l}\text { Brad image --> } \\
\text { Ewom }\end{array}$ & 0.118 & 1.515 & 0.130 & $\begin{array}{l}(+), \\
\text { insignificant, } \\
\text { Hypothesis } \\
\text { not } \\
\text { supported }\end{array}$ \\
\hline $\mathrm{H} 2$ & $\begin{array}{l}\text { Brand image --> } \\
\text { Trust }\end{array}$ & 0.126 & 3.625 & 0.000 & $\begin{array}{l}(+), \\
\text { significant, } \\
\text { Hypothesis } \\
\text { supported }\end{array}$ \\
\hline H3 & $\begin{array}{l}\text { Value co-creation -- } \\
>\text { Ewom }\end{array}$ & 0.109 & 3.148 & 0.002 & $\begin{array}{l}(+), \\
\text { significant, } \\
\text { Hypothesis } \\
\text { supported }\end{array}$ \\
\hline $\mathrm{H} 4$ & $\begin{array}{l}\text { Value co-creation -- } \\
>\text { Brand image }\end{array}$ & 0.059 & 12.639 & 0.000 & $\begin{array}{l}(+), \\
\text { significant, } \\
\text { Hypothesis } \\
\text { supported }\end{array}$ \\
\hline H5 & $\begin{array}{l}\text { Value co-creation -- } \\
>\text { Trust }\end{array}$ & 0.117 & 3.047 & 0.002 & $\begin{array}{l}(+), \\
\text { significant, } \\
\text { Hypothesis } \\
\text { supported }\end{array}$ \\
\hline H6 & Trust --> Ewom & 0.106 & 3.102 & 0.001 & $\begin{array}{l}(+), \\
\text { significant, } \\
\text { Hypothesis } \\
\text { supported }\end{array}$ \\
\hline
\end{tabular}

Source: Secondary Data Processing 2019 
Based on the results of the study, the first hypothesis which states that bramd image have a significant effect on ewom is not supported. From the results of testing the hypothesis 1 that has been done using Partial Least Square (PLS), it was found that brand image can improve ewom but not significantly. This finding is not similar with the previous studies, however, the plausible reason for this finding is that brand image will affect E-WOM significantly through trust as a mediator. Furthermore, this study supports hypothesis 2 which states that brand image have a significant effect on trust. This states that the higher level of brand image, the more level of trust. The results of this study are supported by the research of Severi and Ling (2013) emphasized that a strong brand image can strengthen brand competitiveness. Research Budiman (2015) also supports the results of this study. In hypothesis 3, the results of the study also support this hypothesis which states that value co-creation forms ewom significantly. The hypothesis 4 in this study states that value co-creation affect brand image. This study supported by Ind and Coates (2013) value creation can also influence other stakeholders' perceptions of the company. .In hypothesis 5, the results of the study also support this hypothesis which states that value co-creation forms trust significantly. This reseach supported by (Leadbeater, 2006; Lundkvist \& Yakhlef, 2004), that a higher level of customer co-creation will also result in a higher level of trust among buyers and suppliers. Finally, in hypothesis 6, the results of the study also support this hypothesis which states that trust forms ewom significantly. This is seen from the results of research which states that brand image have a significant and positive effect trust and value co-creation has a significant positive effect ewom. Value co-creation and brand image has a significant positive effect also value co-creation and trust has a positive effect. The last is trust which states that form ewom significantly. Although the results of this study found that the brand iamge did not have a significant effect on ewom.

\section{Conclusions}

The results of this study conclude that brand image have no significant effect on ewom. Brand image has a significant effect on trust and value co-creation has a significant effect on ewom. Value co-creation has a significant effect on brand image and value co-creation has a significant effect on trust. The result also conclude that trust has a significant effect on ewom.

This study has limitations related to the limited number of samples for only 80 students. Apart from this, this study has theoretical implications related to the relationship of the variables studied, namely trust, electronic word of mouth, value co-creation and brand image. Research on value co-creation is still limited in the developing countries such as Indonesia. The results of this study are expected to contribute to the development of future studies related to the value co-creation variable. Furthermore, for the future studies, we suggest expanding the research with a bigger sample size and it might be conducted not only in Padang but also in some areas. Practically, the results of this study can be used as a reference for the managers to build the behavior of value co-creation for the strategy of marketing.

\section{References}

Alves, H., Fernandes, I. C., \& Ferreira, J. J. (2016). Customer's operant resources effects on co-creation activities. Journal of Innovation \& Knowledge, 21(1), 1-12.

Anggraeni, A., \& Rachmanita. (2015). Effects of Brand Love, Personality and Image on Word of Mouth; the Case of Local Fashion Brands Among Young Consumers. Procedia - Social and Behavioral Sciences, 211, 442-447. doi: https://doi.org/10.1016/j.sbspro.2015.11.058

Ayeh, J. K., Au, N., \& Law, R. (2013). Predicting the intention to use consumergenerated media for travel planning. Tourism Management, 35, 132e143.

Banyte, J., \& Dovaliene, A. (2014). Relations between Customer Engagement into Value Creation and Customer Loyalty. Procedia - Social and Behavioral Sciences, 156, 484-489. doi: https://doi.org/10.1016/i.sbspro.2014.11.226

Budiman, A. (2015). Social media and brand image: a study on UNKL347 clothing comp.

Casalo, L. V., Flavi an, C., \& Guinalíu, M. (2011). Understanding the intention to follow the advice obtained in an online travel community. Computers in Human Behavior, 27(2), 622e633. 
Cheung, C. M. K., Lee, M. K. O., \& Thadani, D. R. (2009). The impact of positive electronic word-of-mouth on consumer online purchasing decision. In M. D. Lytras, E. Damiani, J. M. Carroll, R. D. Tennyson, D. Avison, A. Naeve, A. Dale, P. Lefrere, F. Tan, J. Sipior, \& G. Vossen (Eds.), Lecture notes in computer science (Lecture notes in artificial intelligence) (Vol. 5736, pp. 501e510). Berlin, Germany: Springer-Verlag.

Cheung, C. M., Lee, M. K., \& Rabjohn, N. (2008). The impact of electronic word-ofmouth: The adoption of online opinions in online customer communities. Internet Research, 18(3), 229e247.

Chu, S.-C., \& Choi, S. M. (2011). Electronic word-of-mouth in social networking sites: A cross-cultural study of the United States and China. Journal of Global Marketing, 24, $263 \mathrm{e} 281$.

Cossío-Silva, F.-J., Revilla-Camacho, M.-Á., Vega-Vázquez, M., \& Palacios-Florencio, B. (2016). Value cocreation and customer loyalty. Journal of Business Research, 69(5), 1621-1625. doi: https://doi.org/10.1016/j.jbusres.2015.10.028

Dumonceaux MD, Kumar S and Massie C. (2006) Comparative innovative business strategies of major players in cosmetic industry. Industrial Management \& Data Systems 106: 285-306.

Filieri, R., Alguezaui, S., \& McLeay, F. (2015). Why do travelers trust TripAdvisor? Antecedents of trust towards consumer-generated media and its influence on recommendation adoption and word of mouth. Tourism Management, 51, 174-185. doi: https://doi.org/10.1016/j.tourman.2015.05.007

Gensler, S., Völckner, F., Egger, M., Fischbach, K., Schoder, D. (2015). Listen to your customers: insights into brand image using online consumer-generated product reviews. Int. J. Electron. Commer. 20 (1), 112-141.

Hart, P., Saunders, C. (1997). Power and trust: critical factors in the adoption and use of electronic data interchange. Organ. Sci. 8 (1), $23-42$.

Hatch, M.J., Schultz, M., (2010). Toward a theory of brand co-creation with implications for brand governance. J. Brand Manag. 17 (8), 590-604.

Hennig-Thurau, T., Gwinner, K. P., Walsh, G., \& Gremler, D. D. (2004). Electronic word-of-mouth via consumer-opinion platforms: What motivates consumers to articulate themselves on the internet? Journal of Interactive Marketing, 18(1), 38e52.

Hsieh, S. H., \& Chang, A. (2016). The psychological mechanism of brand co-creation engagement. Journal of Interactive Marketing, 33, 13-26.

Ind, N., \& Coates, N. (2013). The meanings of co-creation. European Business Review, 25(1), 86-95.

Jalilvand, M. R., \& Samiei, N. (2012). The impact of electronic word of mouth on a tourism destination choice: Testing the theory of planned behavior (TPB). Internet Research, 22(5), 591e612.

Jalilvand, M. R., Esfahani, S. S., \& Samiei, N. (2011). Electronic word-of-mouth: Challenges and opportunities. Procedia Computer Science, 3, $42 \mathrm{e} 46$.

Karlsen, J.T., Græe, K., Massaoud, M.J. (2008). Building trust in projectstakeholder relationships. Balt. J. Manag. 3 (1), 7-22.

Kementrian Perindustrian Republik Indonesia. (2018, 28 November). Industri Kosmetik Nasional Tumbuh 20\%. Doi: http://www.kemenperin.go.id/artikel/18957/Industri-Kosmetik-Nasional-Tumbuh-20.

Kim, S., Wang, K., Jhu, W., \& Gao, Y. (2016). The best match-up of airline advertising endorsement and flight safety message. International Journal of Contemporary Hospitality Management, 28(11), 2533-2552.

Klein, J. F., Falk, T., Esch, F.-R., \& Gloukhovtsev, A. (2016). Linking pop-up brand stores to brand experience and word of mouth: The case of luxury retail. Journal of Business Research, 69(12), 57615767. doi: https://doi.org/10.1016/j.jbusres.2016.04.172

Kotler, P., \& Keller, K.L. (2016). Marketing Management. 15ethedition. USA: Pearson Education.

Krishnamurthy, A., Kumar, S.R. (2015). Exploring the formation of consumer expectations. J. Cust. Behav. $14(1), 7-31$.

Kumparan. (2017, 24 September). Industri Kosmetik di Indonesia Semakin Cantik. Doi: https://kumparan.com/@kumparannews/industri-kosmetik-di-indonesia-semakin-cantik.

Leadbeater, C. (2006). The user innovation revolution: How business can unlock the value of customers' ideas. The Design Journal: November 2006, 9(3), 59-62. 
Lebeau, Y., Bennion, A. (2014). Forms of embeddedness and discourses of engagement: a case study of universities in their local environment. Stud. High. Educ. 39 (2), 278-293.

Li, X.G., Wang, X., \& Cai, Y.J. (2011). Corporate-, product-, and user-image dimensions and purchase intentions. Journal of Computers, 6(9), 1875-1879.

Lien, C., Wen, M., Huang, L., Wu, K. (2015). Online hotel booking: the effects of brand image, price, trust and value on purchase intentions. Asia Pac. Manag. Rev. 20 (4), 210-218.

Lim, C. H., Chung, J. J., \& Pedersen, P. M. (2012). Effects fo electronic word-of-mouth messages. Sport Management International Journal, 8(1), 55e75.

Lin, T. M., Lu, K.-Y., \& Wu, J.-J. (2012). The effects of visual information in ewom communication. Journal of Research in Interactive Marketing, 6(1), 7e26.

Lundkvist, A., \& Yakhlef, A. (2004). Customer involvement in new service development: A conversational approach. Managing Service Quality, 14(2/3), 249-257.

Mayer, R. C., Davis, J. H., \& Schoorman, F. D. (1995). An integrative model of organizational trust. Academy of Management Review, 20, 709-734

Merz,M.A., He,Y., \& Vargo, S. L.(2009). The evolving brand logic:Aservicedominant logic perspective. Journal of the Academy of Marketing Science, 37(3), 328-344.

Nagar, K. (2015). Modeling the effects of green advertising on brand image: investigating the moderating effects of product involvement using structural equation. J. Glob. Mark. 28, 152-171.

O'Reilly, K., \& Marx, S. (2011). How young, technical consumers assess online WOM credibility. Qualitative Market Research: An International Journal, 14(4), 330e359.

Pan, L.-Y., \& Chiou, J.-S. (2011). How much can you trust online information? Cues for perceived trustworthiness of consumer-generated online information. Journal of Interactive Marketing, 25(2), $67 \mathrm{e} 74$.

Payne, A.F., Storbacka, K., Frow, P., Knox, S. (2009). Co-creating brands: diagnosing and designing the relationship experience. J. Bus. Res. 62 (3), 379-389.

Rastogi S.C., (2003). Natural Ingredients Based Cosmetics (Content of selected fragrance sensitizers). Ministry of Environment and Energy, Nat'l Env'tal Research In'te, Roskilde, Denmark.

Rempel, J., Holmes, J., Zanna, M. (1985). Trust in close relationships. J. Pers. Soc. Psychol. 49 (1), 95.

Rose, J., Schlichter, B.R. (2013). Decoupling, re-engaging: managing trust relationships in implementation projects: managing trust relationships in implementation projects. Inf. Syst. J. 23 (1), 5-33.

Rousseau, D.M., Sitkin, S.B., Burt, R.S., Camerer, C. (1998). Not so different after all: a cross-discipline view of trust. Acad. Manag. Rev. 23 (3), 393-404.

Seraj, M. (2012). We create, we connect, we respect, therefore we are: Intellectual, social, and cultural value in online communities. Journal of Interactive Marketing, 26(4), 209-222.

Severi, E., Ling, K. (2013). The mediating effects of brand association, brand loyalty, brand image and perceived quality on brand equity. Asian Soc. Sci. 9 (3), 125.

Swift, P. E., \& Hwang, A. (2013). The impact of affective and cognitive trust on knowledge sharing and organizational learning. The Learning Organization, 20(1), 20-37.

Thatcher, J., Alao, H., Brown, C.J., Choudhary, S. (2016). Enriching the values of micro and small business research projects: co-creation service provision as perceived by academic, business and student. Stud. High. Educ. 41 (3), 560-581.

Wang, J., Wang, S., Xue, H., Wang, Y., \& Li, J. (2018). Green image and consumers' word-of-mouth intention in the green hotel industry: The moderating effect of Millennials. Journal of Cleaner Production, 181, 426-436. doi: https://doi.org/10.1016/j.jclepro.2018.01.250

Wardi, Yunia \& Abror, Abror \& Trinanda, Okki. (2018). Halal tourism: antecedent of tourist's satisfaction and word of mouth (WOM). Asia Pacific Journal of Tourism Research. 23. 1-10. 10.1080/10941665.2018.1466816.

Xie, X.-Z., Tsai, N.-C., Xu, S.-Q., \& Zhang, B.-Y. (2018). Does customer co-creation value lead to electronic word-of-mouth? An empirical study on the short-video platform industry. The Social Science Journal. doi: https://doi.org/10.1016/j.soscij.2018.08.010 
Zohaib, A., Mukhtar, A.,misbahul, H. (2014). Effect Of Brand Trust and Customer Satisfaction on Brand Loyalty in Bahawalpur. Journal of Sociological Research, Vol. 5, No. 1. 